\title{
Incidence and Survival of Cylindrocladium parasiticum in Peanut Seed
}

\author{
D. L. Glenn and P. M. Phipps, Tidewater Agricultural Research and Extension Center, VPI\&SU, Suffolk, VA 23437; \\ and R. J. Stipes, Department of Plant Pathology, Physiology, and Weed Science, VPI\&SU, Blacksburg, VA 24061
}

\begin{abstract}
Glenn, D. L., Phipps, P. M., and Stipes, R. J. 2003. Incidence and survival of Cylindrocladium parasiticum in peanut seed. Plant Dis. 87:867-871.

Sixty-three commercial seed lots of peanut produced in Virginia were examined for the presence of seed with speckled testae. Speckled seed were present in seed lots from the 1998, 1999, and 2000 growing seasons at average rates of 3,1.2, and $0.6 \%$, respectively. Speckled and normal seed from 19 seed lots were assayed on a medium selective for C. parasiticum. The fungus was isolated from speckled seed at rates ranging from 40 to $96 \%$. C. parasiticum was isolated only from a single normal seed from one seed lot. The pathogen was recovered at high rates from speckled seed immediately after pods had been dried in commercial drying trailers at temperatures up to $35^{\circ} \mathrm{C}$. Ambient temperatures during winter seed storage that fluctuated from -10 to $28^{\circ} \mathrm{C}$ in 1999 and -8 to $33^{\circ} \mathrm{C}$ in 2000 greatly reduced pathogen recovery in speckled seed stored for 16 or 24 weeks. In field plots with naturally infested soil, the number of speckled seed harvested was directly correlated to the number of symptomatic plants in plots on 29 September. Based on this finding, the harvest of seed peanuts in areas of a field with high incidence of Cylindrocladium black rot (CBR) should be avoided. Adoption of this policy is expected to lower the number of speckled seed entering commercial seed lots and reduce the risk for spread of CBR.
\end{abstract}

Additional keywords: Arachis hypogaea, Calonectria ilicicola, Cylindrocladium black rot, groundnut, seed transmission

Cylindrocladium parasiticum Crous, Wingfield \& Alfenas is a soilborne fungus that causes Cylindrocladium black rot (CBR) of peanut (Arachis hypogaea L.), a disease of economic importance to Virginia and North Carolina $(2,3,6)$. Under favorable conditions, overwintering microsclerotia germinate and infect peanut roots, causing decay. Leaves of infected plants appear chlorotic and wilted and infection eventually leads to plant death. Hypocotyls, pegs, pods, and seed are also susceptible to infection. C. parasiticum has been isolated from peanut seed on several occasions $(10,11,13)$. Therefore, disease spread from the planting of infected seed is a concern. In early studies, seed transmission was considered unlikely given that $C$. parasiticum could not be isolated from fungicide-treated seed and discolored seed were removed from commercial seed lots during routine handling procedures $(10,11)$. In recent years, a higher-than-expected incidence of CBR has been observed in some Virginia fields treated with metam

Corresponding author: D. L. Glenn

E-mail: dlglenn@fdwsr.ars.usda.gov

Current address of D. L. Glenn: USDA-ARS Foreign Disease-Weed Science Research Unit, Fort Detrick, MD 21702.

Accepted for publication 26 February 2003.

Publication no. D-2003-0512-02R

(C) 2003 The American Phytopathological Society sodium for control of soilborne inoculum. For this reason, seed transmission of $C$. parasiticum is being reexamined as a potential means of disease spread.

The symptom description of peanut seed with cinnamon-brown speckling on the testae given by Randall-Schadel recently has been related to recovery of $C$. parasiticum (13). Speckled seed are defined as having dots or flecks 0.1 to 0.6 by 0.1 to $0.4 \mathrm{~mm}$ in area clustered on part or all of the testa. Using electron microscopy, Randall-Schadel observed hyphae and microsclerotia of $C$. parasiticum on and within the multicellular layers of the testae of speckled seed (13). Fungal structures were rarely found to penetrate below the inner layer of the testae.

In a survey of 62 commercial seed lots conducted in 1993, speckled seed were found in $\mathrm{VC} 1, \mathrm{NC} 6, \mathrm{NC} 7, \mathrm{NC} 9$, NC 10C, NC-V 11, VA-C 92R, and Florigiant cultivars in the Virginia-North Carolina region (13). C. parasiticum was isolated from speckled seed present in seed lots of $\mathrm{NC} 7$ and $\mathrm{NC} 10 \mathrm{C}$ at rates ranging from 4 to $45 \%$, and recent field trials have indicated that seed transmission of $C$. parasiticum can occur when these seed are planted in fields. The levels of speckled seed and viable inoculum found in recent commercial seed lots in Virginia, including additional cultivars important to the peanut industry such as NC 12C, Gregory, VA 98R, and Perry, have not been determined.

In other seedborne diseases, postharvest measures that include heat treatment can reduce pathogen survival in seed. In rice, sun-drying harvested seed in the field can significantly reduce inoculum levels of Pyricularia oryzae in infected grain (7). Dry heat treatments at temperatures of 71 , 75 , and $84^{\circ} \mathrm{C}$ reduced recovery of Xanthomonas campestris pv. translucens from infected barley seed (5). The conditions encountered during the commercial handling and storage of peanut seed from fall harvest to spring planting may affect survival of $C$. parasiticum in infected seed. Following combining, individual growers will dry whole pods in open trailers using forced air and supplemental heat until seed reach a moisture level around $10 \%(\mathrm{wt} / \mathrm{wt})$. The temperature and duration of pod drying are dependent on weather conditions, but temperatures should not exceed $35^{\circ} \mathrm{C}$, or $8^{\circ} \mathrm{C}$ above ambient temperatures (4). In order to expedite drying large quantities of seed, some growers may dry seed at temperatures higher than those recommended. The effect of high drying temperatures on survival of $C$. parasiticum in speckled seed is not known.

Dried pods are transported to commercial shelling plants where they are shelled and seed are sized, sorted to remove discolored kernels, and stored until spring. Seed should be stored under refrigerated conditions $\left(1\right.$ to $5^{\circ} \mathrm{C}$, with a relative humidity of 55 to $70 \%$ ) in order to preserve seed quality (4). However, specific storage practices may vary among individual shelling plants. A previous study showed that pathogen survival in speckled seed declined when unshelled pods were stored in a warehouse for 8 months; however, viable inoculum was still present in seed at the time of planting (12). Viability of $C$. parasiticum in shelled, speckled seed from commercial seed lots following storage under recommended refrigerated conditions has not been studied.

The objectives of the present study were to determine the levels of speckled seed in commercial seed lots of popular cultivars in Virginia, to confirm the incidence of $C$. parasiticum in speckled seed, to examine the effects of pod drying and winter seed storage temperatures on survival of $C$. parasiticum in peanut seed, and to examine the relationship between CBR incidence and the production of speckled seed in the field.

\section{MATERIALS AND METHODS}

Survey of commercial seed. Seed samples weighing 200 to $1,000 \mathrm{~g}$ were collected from commercial shelling plants after pods were shelled and seed were 
electronically sorted to remove discolored seed. Seed of seven virginia-type peanut cultivars, NC-V 11, NC 7, NC 12C, Gregory, VA-C 92R, VA 98R, and Perry, were sampled. The number of seed lots sampled in 1998, 1999, and 2000 was 5, 20, and 38, respectively. The percentage of speckled seed in a sample was determined by count. The number of speckled seed expected in $45.4 \mathrm{~kg}$ of commercial seed (the quantity often used to plant 0.4 ha or 1 acre) was determined for each seed lot by multiplying the percentage of speckled seed in a sample by the approximate seed count in $45.4 \mathrm{~kg}$ of seed (14).

Seed assays. Commercial shellers began shelling peanut pods from grower fields soon after harvest in November 1999 and continued through January 2000. During this time, seed from 19 different seed lots of four cultivars (VA 98R, NC-V 11, VA-C 92R, and NC 7) were collected as seed lots were shelled. Following collection, 50 seed of each type (normal and speckled) were assayed on the following medium selective for $C$. parasiticum. Peeled potato slices $(200 \mathrm{~g})$ were autoclaved in $500 \mathrm{ml}$ of distilled water for $40 \mathrm{~min}$ at $120^{\circ} \mathrm{C}$ and $103 \mathrm{kPa}$. The resulting potato broth was strained through two layers of cheesecloth and added to $500 \mathrm{ml}$ of distilled water containing $17 \mathrm{~g}$ of melted agar and $20 \mathrm{~g}$ of dextrose. Distilled water was added to yield a final volume of 1 liter and the medium was autoclaved for 10 min at $120^{\circ} \mathrm{C}$ and $103 \mathrm{kPa}$. The medium was amended with pentachloronitrobenzene (PCNB) $(52.5 \mathrm{mg})$, thiabendazole (2.3 mg), chlortetracycline (100 mg), chloramphenicol (100 mg), and dicloran (2 mg).

Table 1. Incidence of speckled seed in commercial seed lots of peanut from the 1998, 1999, and 2000 growing seasons ${ }^{\mathrm{a}}$

\begin{tabular}{|c|c|c|c|}
\hline Year, cultivar & No. seed lots ${ }^{b}$ & Average speckled seed $(\%)^{\mathrm{c}}$ & No. speckled seed $/ 45 \mathrm{~kg}^{\mathrm{d}}$ \\
\hline \multicolumn{4}{|l|}{1998} \\
\hline NC-V 11 & 1 & 4.0 & 2,400 \\
\hline VA-C 92R & 1 & 1.6 & 880 \\
\hline NC 7 & 1 & 4.0 & 2,000 \\
\hline $\mathrm{NC} 12 \mathrm{C}$ & 1 & 3.0 & 1,500 \\
\hline Gregory & 1 & 2.2 & 990 \\
\hline Yearly average & $\ldots$ & 3.0 & 1,554 \\
\hline \multicolumn{4}{|l|}{1999} \\
\hline VA 98R & 8 & 1.5 & 825 \\
\hline NC-V 11 & 4 & 1.9 & 1,125 \\
\hline VA-C 92R & 3 & 0.9 & 513 \\
\hline NC 7 & 5 & 0.5 & 260 \\
\hline Yearly average & $\ldots$ & 1.2 & 697 \\
\hline \multicolumn{4}{|l|}{2000} \\
\hline VA 98R & 5 & 1.0 & 550 \\
\hline NC-V 11 & 7 & 0.3 & 206 \\
\hline VA-C 92R & 6 & 0.5 & 394 \\
\hline NC 7 & 14 & 0.9 & 439 \\
\hline $\mathrm{NC} 12 \mathrm{C}$ & 3 & 0.5 & 267 \\
\hline Perry & 3 & 0.0 & 0 \\
\hline Yearly average & $\ldots$ & 0.6 & 355 \\
\hline
\end{tabular}

a Speckled seed $=$ seed with cinnamon-brown speckling on the testae (13).

${ }^{b}$ Seed lots sampled after routine conditioning procedures at a commercial shelling plant.

${ }^{c}$ Percentages determined by seed count.

${ }^{\mathrm{d}}$ Estimates based on the percentage of speckled seed in a sample and count per $454 \mathrm{~g}$ of seed for each cultivar.

Seed with intact testae were rinsed for 1 min under running water, cut latitudinally, and disinfested in a $0.26 \%$ sodium hypochlorite solution for $1 \mathrm{~min}$. Both cut ends were placed in contact with the medium and five seed were assayed per petri plate. Plates were incubated at room temperature and observed for growth of $C$. parasiticum at regular intervals for 14 days.

After initial seed assays, speckled seed were stored in polyethylene bags in an incubator at $15^{\circ} \mathrm{C}$. Fifty speckled seed from each seed lot were assayed again in June 2000 in order to determine the recovery rate of $C$. parasiticum from seed in early summer, soon after seed are routinely planted in the field. Seed lots were collected from shelling plants over a 3-month period; therefore, the duration between the initial and final seed assay varied among seed lots and ranged from 80 to 189 days.

Seed storage temperatures and pathogen survival. Two cultivars ( $\mathrm{NC}-\mathrm{V} 11$ and VA 98R) were chosen to periodically examine the effect of controlled and ambient storage temperatures on survival of $C$. parasiticum in speckled seed. In 1999 and 2000 , seed were collected from a commercial shelling plant and 50 speckled seed from one seed lot of each cultivar were assayed in January to determine initial pathogen recovery. Seed then were placed in cardboard boxes ( 8 by 6 by $5.5 \mathrm{~cm}$ ) and stored in an unheated building and at con199 temperatures of $-13,4$, and $15^{\circ} \mathrm{C}$ in Differences in controlled temperatures in 1999 and 2000 were due to inconsistencies in equipment. Fifty seed were removed from each storage condition and assayed in March and again in May after 8 and 16

868 Plant Disease / Vol. 87 No. 7 weeks of storage, respectively. In 1999, seed of NC-V 11 initially were assayed in November and assayed again at 8, 16, and 24 weeks after storage (January, March, and May, respectively). Maximum and minimum air temperatures were recorded for each storage location. For each seed lot, Duncan's new multiple range test $(P=$ 0.05) was utilized to separate treatment means within each storage interval (SAS 8.0; SAS Institute Inc., Cary, NC).

Pod drying. Whole pods of VA 98R were obtained from a field having a high incidence of CBR in 2000. Pods were dug and harvested in October, separated into $4.5-\mathrm{kg}$ samples, and placed in nylon-mesh bags. Samples were dried indoors using forced air (no heat) or outdoors in commercial drying trailers using forced air with supplemental heat. Watchdog weather sensors (Spectrum Technologies, Concord, $\mathrm{NH})$ were placed in each sample bag and temperatures were recorded every $15 \mathrm{~min}$. Samples to be dried with heat were secured at the bottom, middle, and top level $(0,0.7$, and $1.4 \mathrm{~m}$ ) of drying trailers. Sample bags placed in the bottom of the trailer were closest to the source of air and heat. Trailers then were filled with pods harvested from commercial grower fields. Pods were dried until they reached moisture levels required for pod shelling. Sample bags were removed, pods were shelled, and seed were sorted into normal and speckled seed. Fifty speckled seed were assayed from each sample as previously described. Five trials were conducted using different drying trailers at several locations in Suffolk, VA. Trials were conducted in October over a 12-day period as drying trailers became available from cooperative local growers. Levels of heat applied to drying trailers were decided upon by the growers and were dependent on outdoor temperatures at the time of pod drying. Duncan's new multiple range test $(P=$ $0.05)$ was utilized to separate means for each drying condition. Means were averages from five trials.

CBR incidence and speckled seed. Fifteen field plots having a wide range of CBR incidence on 29 September 2000 (7 to 173 symptomatic plants $/ 30.5 \mathrm{~m}$ or $100 \mathrm{ft}$ of row) were selected to determine the relationship between aboveground disease symptoms and the production of speckled seed. Routine management practices (9) were followed for the control of other common pathogens of peanut including Sclerotinia minor, Sclerotium rolfsii, and Rhizoctonia solani. CBR incidence was measured as the number of wilted or dead plants per plot. Plant damage due to diseases other than CBR was minimal. Field plots were selected from three field trials in Suffolk, VA planted with either NC-V 11 or VA 98R. Plots were dug in early October and pods were harvested on 10 October with a two-row, Amadas combine having a bagger attachment for plot re- 
search. Whole pods were dried with forced air and supplemental heat as recommended in the region until seed reached about 8 to $10 \%$ moisture content. Pods then were shelled and seed retained on a 6.4-by-25.4$\mathrm{mm}$ slotted screen were sampled. For each field plot, a sample weighing $1.5 \mathrm{~kg}$ was collected and the number of speckled seed in each sample counted. A linear regression model in SAS was utilized to determine if the percentage of speckled seed was correlated $(P=0.01)$ to aboveground disease incidence.

\section{RESULTS}

Survey of commercial seed. Speckled seed were found in 59 of the 63 seed lots sampled (Table 1). In 1998, 1999, and 2000 , the average percentage of speckled seed in all samples was 3, 1.2, and $0.6 \%$, respectively. The percentage of speckled seed across all years ranged from 0 to $4 \%$ and averaged $1 \%$. The estimated number of speckled seed in a 45.4-kg sample ranged from 0 to 2,400 .

Incidence of $C$. parasiticum in seed collected from commercial shelling plants. Among the 19 seed lots, pathogen recovery in speckled seed ranged from 40 to $96 \%$ when seed were assayed following collection from shelling plants during November 1999 to January 2000 (Table 2). Twelve lots had isolation frequencies of $80 \%$ or higher. C. parasiticum was isolated from only one normal seed of VA 98R. Other fungal pathogens of peanut isolated from seed included Aspergillus niger, Rhizopus sp., and S. rolfsii. The occurrence of these fungi showed no apparent relationship to seed with speckled testae.

In June 2000, after seed lots had been stored at $15^{\circ} \mathrm{C}$ following collection from shelling plants, C. parasiticum was isolated from all 19 seed lots (Table 2). Recovery rates in June were lower for all seed lots compared with initial recovery rates. At the time of the second assay in June, recovery rates ranged from 4 to $78 \%$. Rates were above $60 \%$ in all four seed lots of NC-V 11 and one of three seed lots of VA-C 92R. Lot 337 of VA-C 92R was heavily colonized by Rhizopus sp., making identification of $C$. parasiticum difficult.

Seed storage temperatures and pathogen survival. Ambient temperatures over the duration of the study in 1999 ranged from -10 to $28^{\circ} \mathrm{C}$, with an average weekly minimum and maximum of 3 and $18^{\circ} \mathrm{C}$, respectively. Before storage, C. parasiticum was isolated from 1999 seed of VA $98 \mathrm{R}$ at a rate of $76 \%$. In May, after 16 weeks of storage, pathogen recovery was significantly lower in seed stored under ambient conditions compared with all other treatments (Fig. 1A). Recovery rates were $62,76,38$, and $12 \%$ for seed stored at -13 , 4 , and $15^{\circ} \mathrm{C}$ and ambient conditions, respectively. In $\mathrm{NC}-\mathrm{V} 11$, the initial recovery rate was $97 \%$ before storage and rates were similar among all treatments until May, at 24 weeks after storage. At that time, recovery was significantly lower in seed stored under ambient conditions compared with all other treatments (Fig. 1B). C. parasiticum was isolated from seed stored at $-13,4$, and $15^{\circ} \mathrm{C}$ and ambient conditions at rates of $92,88,82$, and $28 \%$, respectively.

In 2000, ambient storage temperatures ranged from -8 to $33^{\circ} \mathrm{C}$. As in 1999 , storage of VA 98R and NC-V 11 seed at ambient conditions resulted in the lowest pathogen recovery rates by the end of the study in May (Fig. 1C and D). In VA 98R, recovery rates were significantly lower in seed stored under ambient conditions compared with all other treatments. The initial recovand $4 \%$, after storage at $-24,5$, and $13{ }^{\circ} \mathrm{C}$ and ambient temperatures, respectively. In NC-V 11, an initial recovery rate of $78 \%$ was reduced to $42,34,18$, and $8 \%$ at the respective temperatures. Pathogen recovery in seed stored under ambient conditions was significantly lower than all other treatments except storage at $13^{\circ} \mathrm{C}$ for $\mathrm{NC}$ V 11 in 2000.

Pathogen survival after pod drying. Temperatures encountered during the drying of pods varied among drying conditions as well as among the five trials. The maximum temperatures in each trial were highest in drying trailers near the source of heat (i.e., bottom of trailers) and lowest indoors where pods were air dried with no ery rate of $68 \%$ was reduced to $50,44,26$,

supplemental heat (Table 3). C. parasiticum survived at high rates $(\geq 97 \%)$ in speckled seed dried under all conditions (Table 3).

CBR incidence and speckled seed. Speckled seed were present in all 15 samples from field plots where plants had exhibited symptoms of CBR. The percentage of speckled seed ranged from 1.5 to $12.3 \%$. A significant linear relationship $\left(r^{2}=0.70\right)$ existed between CBR incidence in the field and the percentage of speckled seed produced (Fig. 2). Field plots having a high incidence of CBR led to the production of greater numbers of speckled seed than those with low disease incidence.

\section{DISCUSSION}

CBR can be found in approximately $75 \%$ of Virginia's peanut acreage; therefore, it is not surprising that infected seed are produced in commercial fields. Metam sodium is routinely applied under bedded soil 2 weeks prior to planting in fields heavily infested with $C$. parasiticum (9). Under favorable conditions, the chemical converts to methyl-isothiocyanate (MIT) and diffuses upward through soil, killing soilborne inoculum in the area of taproot growth $(8,15)$. When pods develop outside the treated zone, they may become infected and result in the production of speckled seed.

In a 1993 survey of 62 commercial seed lots from the North Carolina-Virginia

Table 2. Recovery of Cylindrocladium parasiticum from speckled peanut seed from 19 seed lots following collection from commercial shelling plants (November 1999 to January 2000) and again in June 2000 after storage at $15^{\circ} \mathrm{C}$

\begin{tabular}{|c|c|c|c|}
\hline \multirow[b]{2}{*}{ Cultivar/seedlot } & \multirow[b]{2}{*}{ Date of initial assay } & \multicolumn{2}{|c|}{ Seed assay $(\% \text { positive })^{a}$} \\
\hline & & Initial & June 2000 \\
\hline \multicolumn{4}{|l|}{ VA 98R } \\
\hline 314 & 23 November 99 & 90 & 32 \\
\hline 315 & 23 November 99 & 88 & 8 \\
\hline 316 & 23 November 99 & 94 & 18 \\
\hline 318 & 11 December 99 & 88 & 4 \\
\hline 319 & 11 December 99 & 66 & 12 \\
\hline 320 & 11 December 99 & 64 & 6 \\
\hline 321 & 12 December 99 & 44 & 6 \\
\hline Average & $\ldots$ & 76 & 12 \\
\hline \multicolumn{4}{|l|}{ NC-V 11} \\
\hline 322 & 30 December 99 & 90 & 78 \\
\hline 323 & 30 December 99 & 88 & 72 \\
\hline 324 & 13 January 00 & 86 & 74 \\
\hline 325 & 19 January 00 & 96 & 68 \\
\hline Average & $\ldots$ & 90 & 73 \\
\hline \multicolumn{4}{|l|}{ VA-C 92R } \\
\hline 330 & 22 December 99 & 82 & 64 \\
\hline 331 & 23 December 99 & 86 & 48 \\
\hline 337 & 13 January 00 & 80 & $6^{\mathrm{b}}$ \\
\hline Average & $\ldots$ & 83 & 39 \\
\hline \multicolumn{4}{|l|}{$\mathrm{NC} 7$} \\
\hline 338 & 19 January 00 & 80 & 22 \\
\hline 339 & 21 January 00 & 76 & 20 \\
\hline 340 & 22 January 00 & 74 & 10 \\
\hline 341 & 12 March 00 & 40 & 18 \\
\hline 342 & 12 March 00 & 40 & 14 \\
\hline Average & $\ldots$ & 62 & 17 \\
\hline
\end{tabular}

${ }^{\text {a }}$ Data are recovery percentages of $C$. parasiticum from 50 seed. Seed were assayed on a selective medium.

b Seed heavily colonized by Rhizopus sp., making recognition of C. parasiticum difficult. 
growing region, Randall-Schadel reported that speckled seed were present at rates from 0 to $5.6 \%$, with an average occurrence of $1.3 \%$ (13). In the current study, commercial seed lots from Virginia were sampled in 1998, 1999, and 2000. During these years, the estimated yield loss due to CBR in the state was 3,4 , and $8 \%$ of total potential yield in the absence of symptoms. Total acreage planted to peanut was comparable $(75,000,76,000$, and
75,000) among all 3 years (1). Speckled seed were found in seed lots at average rates of $3,1.2$, and $0.6 \%$ in 1998,1999 , and 2000, respectively. Cooperative work with shellers of seed peanuts may be responsible for the low levels of speckled seed present in seed lots in 2000 despite high levels of CBR that year. Current sorting practices do not remove all speckled seed from seed lots. However, it is expected that increased awareness of the
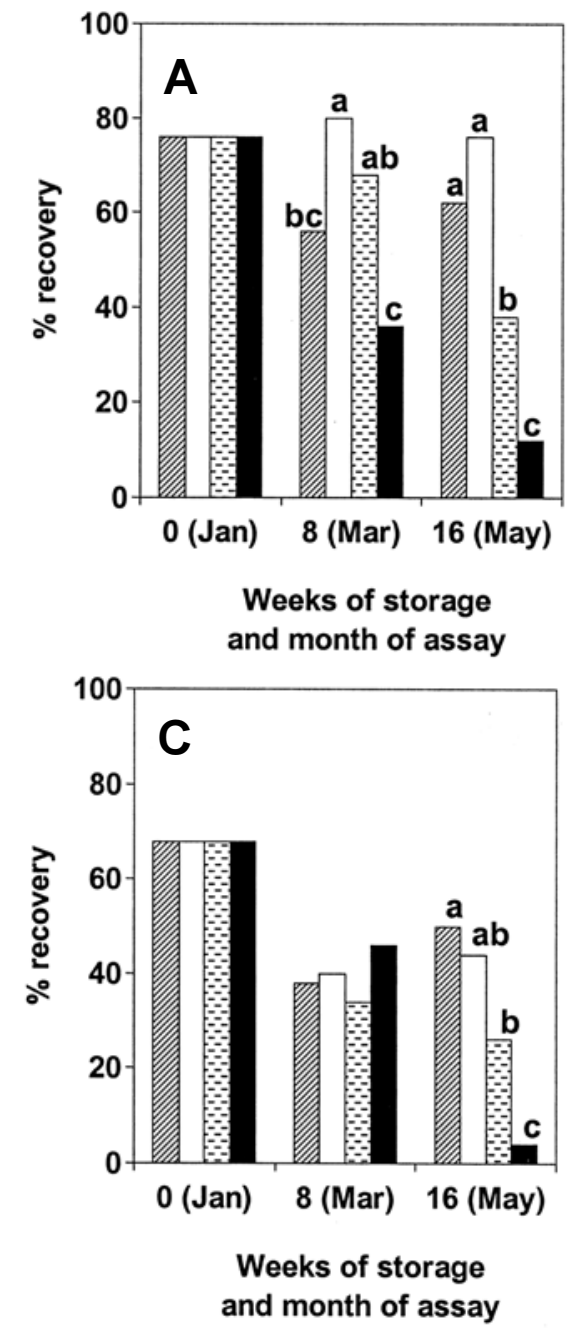
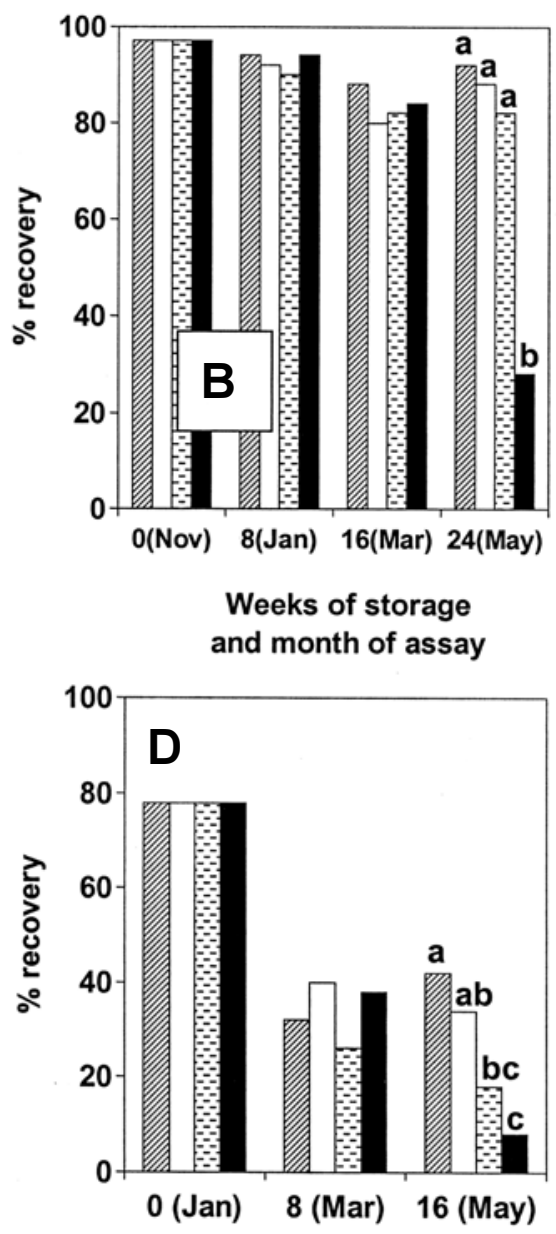

Weeks of storage and month of assay

Fig. 1. Recovery of Cylindrocladium parasiticum from speckled peanut seed during winter storage at ambient and controlled temperatures in 1999 A, VA 98R and B, NC-V 11, and 2000 C, VA 98R and D, NC-V 11. Bars with the same letter or no letters are not significantly different according to Duncan's new multiple range test $(P=0.05)$. Bars from left to right are $-13,4$, and $15^{\circ} \mathrm{C}$ and ambient $\left(-10\right.$ to $\left.28^{\circ} \mathrm{C}\right)$ in 1999 and $-24,5$, and $13^{\circ} \mathrm{C}$ and ambient $\left(-8\right.$ to $\left.33^{\circ} \mathrm{C}\right)$ in 2000 .

problem will reduce the number of infected seed entering commercial seed lots in coming years.

Randall-Schadel recovered $C$. parasiticum from speckled seed harvested from research plots of $\mathrm{NC} 9, \mathrm{NC} 10 \mathrm{C}$, and $\mathrm{NC}$ $\mathrm{V} 11$ at rates of 32,53 , and $42 \%$, respectively (13). In the current study, the pathogen was recovered from speckled seed from commercial seed lots of VA 98R, NCV 11, VA-C 92R, and NC 7 at comparable or higher rates. Of the 19 seed lots assayed, pathogen recovery ranged from 40 to $96 \%$ when seed were assayed following collection from shelling plants. Seed lots may have encountered varied conditions prior to our collection from shelling plants, leading to differences in pathogen survival and recovery. Additional studies in which conditions are monitored immediately following pod harvest through winter seed storage may reveal key factors responsible for differences in pathogen recovery among seed lots. C. parasiticum was isolated from only one normal seed in one seed lot of VA 98R.

The pathogen was isolated from speckled seed of all 19 seed lots again in June 2000 after seed were maintained at $15^{\circ} \mathrm{C}$ following initial assays. Recovery rates were greater than $60 \%$ in four seed lots of NC-V 11 and one seed lot of VA-C 92R. With these high recovery rates, it is possible that these seed could have introduced viable inoculum to commercial grower fields if they had been stored under similar conditions $\left(15^{\circ} \mathrm{C}\right)$ and sold for planting. All other seed lots had recovery rates of less than $48 \%$. Due to differences in duration between initial and June 2000 assays, direct comparisons in pathogen survival rates among seed lots and cultivars cannot be made. Future studies should examine the significance of cultivar in pathogen survival in speckled seed. Physiological or chemical characteristics of the seed testae may impact survival of C. parasiticum.

High temperatures (up to $35^{\circ} \mathrm{C}$ ) encountered during routine pod drying in commercial drying trailers had no significant impact on survival of $C$. parasiticum in seed. Pathogen recovery remained high when pods were dried using forced air with or without supplemental heat. In 2000 , warm ambient temperatures and dry

Table 3. Recovery of Cylindrocladium parasiticum from speckled peanut seed of VA $98 \mathrm{R}$ after pods were dried indoors using forced air without supplemental heat or outdoors using forced air with supplemental heat at three positions within commercial drying trailers (top, middle, and bottom) in 2000

\begin{tabular}{|c|c|c|c|c|c|c|}
\hline \multirow[b]{2}{*}{ Drying condition } & \multicolumn{5}{|c|}{ Maximum temperature $\left({ }^{\circ} \mathbf{C}\right)^{\mathbf{a}}$} & \multirow[b]{2}{*}{ Seed assay $(\% \text { positive })^{b}$} \\
\hline & Trial 1 & Trial 2 & Trial 3 & Trial 4 & Trial 5 & \\
\hline Air & 26.6 & 22.5 & 27.0 & 27.5 & 26.5 & 97.6 \\
\hline Heat, top & 32.5 & 24.8 & 27.8 & 26.8 & 26.5 & 98.0 \\
\hline Heat, middle & 33.5 & 28.3 & 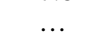 & 30.8 & 27.0 & 98.4 \\
\hline Heat, bottom & 35.4 & 30.0 & 33.5 & 32.3 & 29.5 & 97.6 \\
\hline
\end{tabular}

${ }^{a}$ Maximum temperature reached at each drying condition from five separate trials conducted over a 12-day period.

b Data are recovery percentages of $C$. parasiticum from 50 seed averaged across five trials. Seed were assayed on a selective medium. Means were not significantly different according to Duncan's new multiple range test $(P=0.05)$. 
conditions following harvest provided ideal conditions for pod drying in the field. As a result, the need for supplemental heat in drying trailers to further reduce seed moisture to recommended levels was minimal. Longer exposure to high temperatures encountered during pod drying may have a greater effect on pathogen survival in years with normal rainfall during harvest.

In the present study, recovery of $C$. parasiticum declined in all four seed lots of VA 98R and NC-V 11 during winter seed storage at all temperature treatments. However, C. parasiticum still was isolated from some speckled seed at high rates by the end of the study. The fungus survived well in speckled seed stored at temperatures recommended for commercial winter seed storage $\left(1\right.$ to $\left.5^{\circ} \mathrm{C}\right)$ (4). In May, when seed are planted in Virginia, C. parasiticum was recovered from speckled seed of NC-V 11 and VA 98R at storage at $4{ }^{\circ} \mathrm{C}$ throughout the winter of 1999. Based on the present study, storing seed at ambient temperatures can greatly reduce pathogen survival, thereby reducing the risk for spread of CBR from seedborne inoculum. Temperature fluctuations encountered in ambient storage may be responsible for the reduction in pathogen survival. Further research may reveal ideal winter storage temperatures for complete eradication of $C$. parasiticum in peanut seed.

The wide variation in pathogen survival in speckled seed among seed lots makes it rates of 88 and $76 \%$, respectively, after

difficult to predict the overall role these seed have in dispersal of $C$. parasiticum. Not all speckled seed pose an equal threat for spread of CBR. However, in some commercial lots, infected seed are present and seedborne $C$. parasiticum remains viable at high rates at planting. Therefore, seed transmission of $C$. parasiticum poses a threat for spread of CBR.

In the present study, the percentage of speckled seed harvested was directly correlated to the number of plants with aboveground disease symptoms. Previous research also has noted a significant linear relationship between disease incidence in the field and the percentage of speckled seed produced in some cultivars (12). These findings suggest that the levels of speckled seed entering the commercial seed industry can be reduced if seedsmen avoid harvesting peanuts for seed in areas of the field where CBR incidence is high. A linear regression model based on data over multiple years may be useful in determining a practical allowable limit for CBR incidence in seed production fields. Careful scouting for CBR incidence prior to harvest will identify areas within fields that exceed the recommended disease threshold and should be avoided during harvest. The number of speckled seed can be further reduced as shellers continue to remove darkened seed during already established routine cleaning procedures. For speckled seed that escape the above management strategies, application of a seed treatment

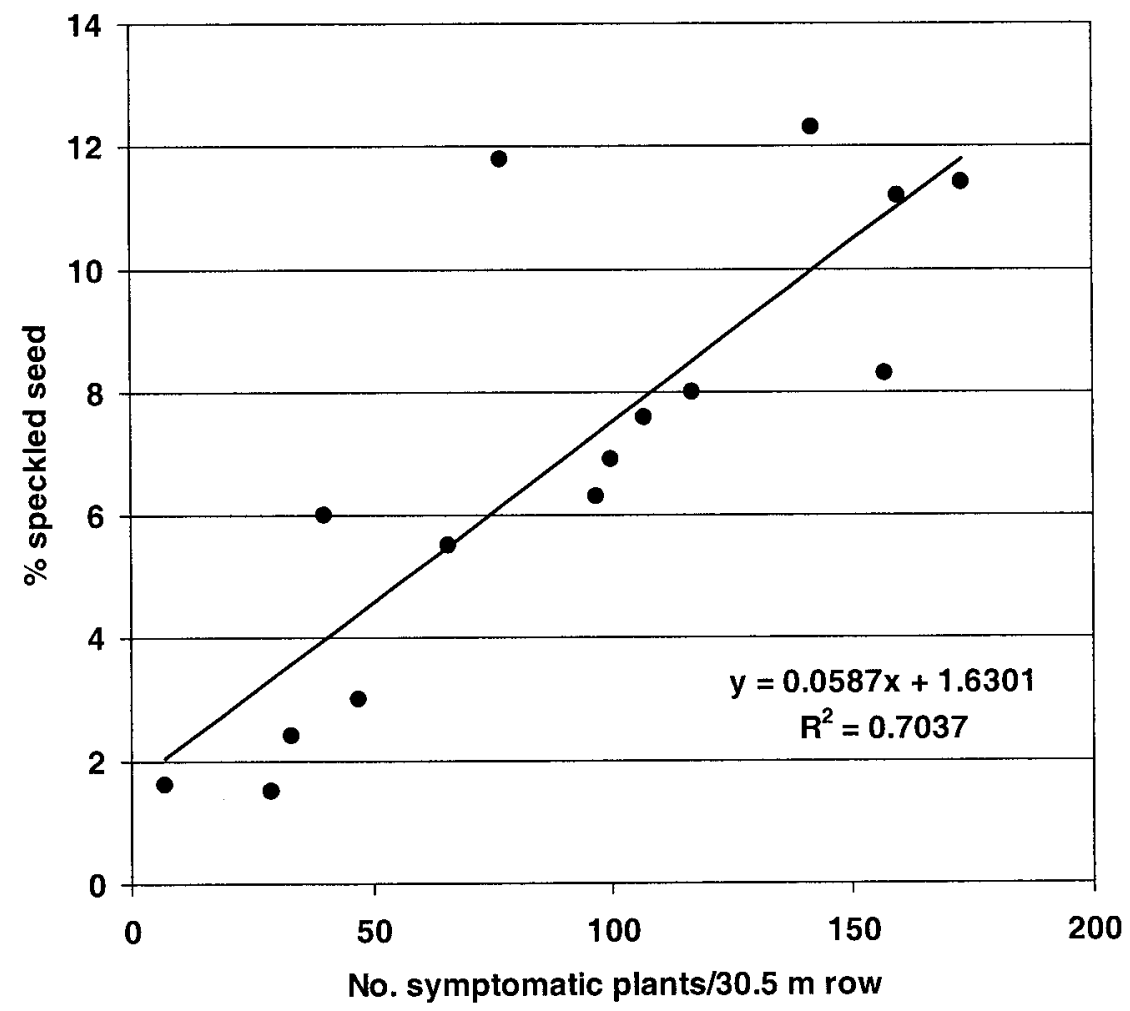

Fig. 2. Relationship between aboveground symptoms of Cylindrocladium black rot and the percentage of speckled seed harvested from test plots in 2000. Data are from 15 samples collected from field plots planted with NC-V 11 or VA 98R. fungicide effective against $C$. parasiticum will reduce the risk of seed transmission in the field. The continued cooperative efforts of researchers, seedsmen, and shellers can minimize the spread of CBR from speckled seed.

\section{ACKNOWLEDGMENTS}

We thank the Virginia Peanut Board for funding the project; and B. Keeling, S. Byrum, E. Hobbs, and B. McMurtrey at the Tidewater Agricultural Research and Extension Center for their valuable assistance in this study.

\section{LITERATURE CITED}

1. Anonymous. 2001. Virginia Agricultural Statistics Bulletin and Resource Directory 2000. Cooperative publication of Va. Dep. Agric. \& Cons. Serv. and USDA Dep. Agric. Natl. Agric. Stat. Ser. Publ. No. 75

2. Bell, D. K., and Sobers, E. K. 1966. A peg, pod, and root necrosis of peanuts caused by a species of Calonectria. Phytopathology 56:1361-1364.

3. Crous, P. W., Wingfield, M. J., and Alfenas, A. C. 1993. Cylindrocladium parasiticum sp. nov., a new name for $C$. crotalariae. Mycol. Res. 97:889-896.

4. Davidson, J. I., Jr., Lamb, M. C., Butts, C. L., Williams, E. J., and Singletary, M. 1995. Applications of expert systems in peanut production. Pages 419-455 in: Advances in Peanut Science. H. E. Pattee and H. T. Stalker, eds. American Peanut Research and Education Society, Inc., Stillwater, OK.

5. Fourest, E., Rehms, L. D., Sands, D. C., Bjarko, M., and Lund, R. E. 1990. Eradication of Xanthomonas campestris pv. translucens from barley seed with dry heat treatments. Plant Dis. 74:816-818.

6. Garren, K. H., Porter, D. M., and Allison, A. H. 1971. Cylindrocladium black rot of peanuts in Virginia. Plant Dis. Rep. 55:419421.

7. Manandhar, H. K., Jorgensen, H. J. L., Smedegaard-Peterson, V., and Mathur, S. B. 1998. Seedborne infection or rice by Pyricularia oryzae and its transmission to seedlings. Plant Dis. 82:1093-1099.

8. Phipps, P. M. 1990. Control of Cylindrocladium black rot of peanut with soil fumigants having methyl isothiocyanate as the active ingredient. Plant Dis. 74:438-441.

9. Phipps, P. M. 2000. Peanut diseases. Pages 62-71 in: 2000 Virginia Peanut Production Guide, C. W. Swann, ed. Virginia Polytechnic Institute and State University, Suffolk. TAREC Inf. Ser. 430.

10. Porter, D. M., and Mozingo, R. W. 1986 Importance of seed transmission in the spread of Cylindrocladium crotalariae. Peanut Sci. 13:80-82.

11. Porter, D. M., Wright, F. S., Taber, R. A., and Smith, D. H. 1991. Colonization of peanut seed by Cylindrocladium crotalariae. Phytopathology 81:896-900.

12. Randall-Schadel, B. L. 1999. Seed transmission of Cylindrocladium parasiticum in peanut (Arachis hypogaea L.). Ph.D. dissertation. North Carolina State University, Raleigh.

13. Randall-Schadel, B. L. 2001. Seed transmission of Cylindrocladium parasiticum in peanut. Plant Dis. 85:362-370.

14. Swann, C. W. 2000. Agronomic recommendations and procedures. Page 11 in: 2000 Virginia Peanut Production Guide. C. W. Swann, ed. Virginia Polytechnic Institute and State University, Suffolk. TAREC Inf. Ser. 430.

15. Turner, N. J., and Corden, M. E. 1963. Decomposition of sodium n-methyldithiocarbamate in soil. Phytopathology 53:13881394. 